\title{
Study of the Physical and Structural Properties of some Local Ninivites and Effect of Doping with some Chromium Complexes
}

\author{
Regab A. Buker \\ Department of Chemistry \\ College of Education \\ Mosul University
}

\author{
Asem S. AL-Botani \\ Department of Chemistry \\ College of Science \\ Mosul University
}

(Received 8/10/2008 ; Accepted 26/1/2009)

\begin{abstract}
Chemical composition, physical properties and structural characterization of natural Ninivite silica rocks have been studied. The study approach is based on using X-ray diffraction and fluorescence, differential and gravimetric thermal analysis, infrared spectroscopy, instrumental and classical chemical analysis techniques.

The results were compared with those obtained from a locally prepared and purified amorphous silica gel. Both samples were doped by selenato and oxalato chromium complexes in order to be a more active and selective adsorbent materials. Chromatographic columns were set for all the above types of adsorbents using four eluants gradually increased in polarity. The fractionation results showed significant variations in the fractions isolated according to their polarities as indicated by percentage results.
\end{abstract}

\section{درلسة الخواه الفيزبائية والنركيبية لصخور نيفليت المحلية وتلثير طاعيمها

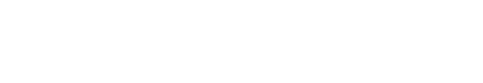

\section{الملهص}

قم درلسة الخواص الفيزيائية والتركيب البلوري والتكوين الكيميائي لنموذج من صخور النيفايت الغنية

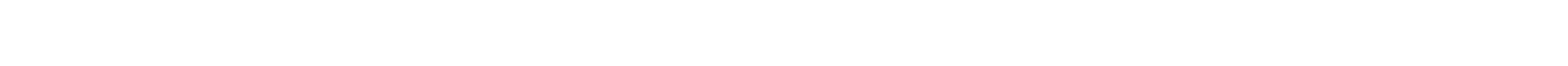
الحرارية الفاضلية والوزنية والتحليل الكيميائي الالي. وم مقارنة النتائج المستحصلة مع نموذج اللسيليكايكا غيلير

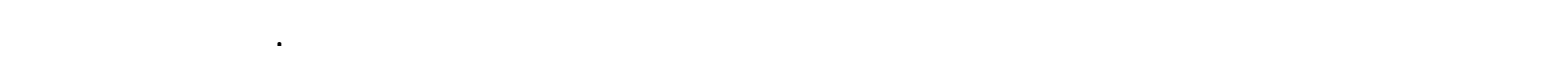

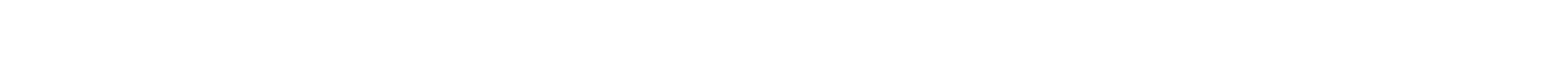

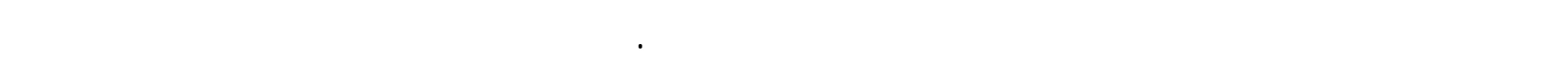

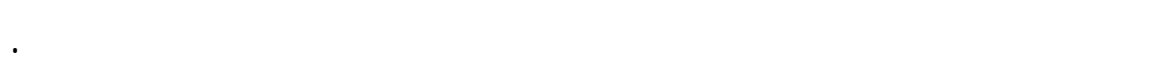




\section{INTRODUCTION}

Ninivite silica rocks located in massive deposits around the city of Mosul in northern Iraq; discovered after Jassim and AL-Naqib, 1989; are considered to be one of the unique sources of amorphous silica (or silica gel). Such silica has been used as a catalyst for a long period in industry in general and especially in petroleum and petrochemicals. This consideration arises form the fact that such materials accompanied in their locations with heavy crude oil reserves. In other words, Hammam Al-Alil bitument and Qaiyarah heavy crude oil might be useful at the present time and have a promising future as well (Ramadhan and Ghazal, 2004).

The demand for all kinds of fossil fuel sources such as heavy Crude Oils, as alternative energy sources to petroleum has been the subject for many workers (Ali et al., 1990; Ramadhan, 1992; Buker and Taher, 2006). Such materials contain a mixture of complex hydrocarbon compounds that can easily be separated by fractionation processes to light fuels and petrochemicals (Buker and AL-Mallah, 2005).

Meanwhile, Ninivite silica rocks and their manufactured compounds (Buker and Taher, 2000, 2006; Kob et al., 1997; Kang and Choi, 2000) are proposed to be good adsorbents and catalysts in the above refining processes. Recently, adsorption of a considerable number of Iraqi heavy crude oils on silica materials have been reported (Buker and Taher, 2000).

As a continuation of these studies Buker and Taher, 2006, in their investigation applied Ninivite silica gel doped with chromium oxides in solid phase extraction. Iraqi virgin olive oil was separated into its simple and useful components. The present study covers an investigation into the application of natural Ninivite and amorphous silica after doping them with some chromium complexes in petroleum refining. They have to be employed as a catalysts in adsorption chromatography to fractionate Qaiyarah petrolene (QP) (Ramadhan, 1992).

\section{A. Sources and Collection of Samples:}

\section{EXPERIMENTAL}

Silica gel bearing Ninivite silica rocks were used as a natural silica gel, which were obtained from area around Mosul city/Iraq. These samples were treated basically according to the literature (Buker and Taher, 2000) to obtain the prepared purified silica gel sample. All samples were chemically formulated following several chemical analysis methods (Skoog and West, 1976).

\section{B. Preparation of Complexes:}

Selenato chromium complex was prepared according to the reported procedure (Salib and Buker, 1983) and following equation (1). Similarly, oxalato chromium complex was prepared applying equation (2) which was reported (Booth, 1939).

$$
\begin{aligned}
& 3 \mathrm{Na}_{2} \mathrm{SeO}_{3}+3 \mathrm{Cr}\left(\mathrm{NO}_{3}\right)_{3} \cdot 9 \mathrm{H}_{2} \mathrm{O}+3 \mathrm{NaOH} \rightarrow \mathrm{Cr}_{2}\left(\mathrm{SeO}_{3}\right)_{3} \cdot \mathrm{Cr}(\mathrm{OH})_{3} \cdot 18 \mathrm{H}_{2} \mathrm{O}+9 \mathrm{NaNO}_{3}+9 \mathrm{H}_{2} \mathrm{O} \ldots \ldots \ldots . .(1) \\
& \mathrm{K}_{2} \mathrm{Cr}_{2} \mathrm{O}_{7}+7 \mathrm{H}_{2} \mathrm{C}_{2} \mathrm{O}_{4} \cdot 2 \mathrm{H}_{2} \mathrm{O}+2 \mathrm{~K}_{2} \mathrm{C}_{2} \mathrm{O}_{4} \cdot \mathrm{H}_{2} \mathrm{O} \rightarrow 2 \mathrm{~K}_{3}\left[\mathrm{Cr}\left(\mathrm{C}_{2} \mathrm{O}_{4}\right)_{3}\right] \cdot 3 \mathrm{H}_{2} \mathrm{O}+6 \mathrm{CO}_{2}+\mathrm{H}_{2} \mathrm{O} \ldots \ldots \ldots . . .(2)
\end{aligned}
$$




\section{Doping of Silica Samples:}

Both samples, natural and the purified silica were doped with selenato and oxalato complexes applying the impregnation methods (Buker and Taher, 2006) to prepare four doped samples. Chromium complexes were mixed with silica samples in a ratio 1:8 mole respectively, stirred with distilled water and small amount of ethanol for several hours, filtered, dried at $110 \mathrm{C}^{\circ}$, and heated at $320 \mathrm{C}^{\circ}$ for 2 hours.

\section{X-ray Powder Diffraction and Fluorescence:}

$\mathrm{X}$-ray powder diffraction studies were carried out using $\mathrm{Cu} \mathrm{K}_{\alpha}$ radiation, and diffraction patterns were recorded using Phillips powder X-ray diffractometer fitted with a vertical goniometry. The phase contributing to the X-ray diffraction patterns were identified by reference to the joint Committee on Powder Diffraction Standers Powder Diffraction File. Meanwhile, X-ray fluorescence data were obtained using Phillips Pw 1450/10 Fluorescence Analyzer.

\section{E. Thermal analysis:}

Thermo-Gravimetric (TG) and Differential-Thermal Analysis (DTA) were recorded between 25 and $650 \mathrm{C}^{\circ}$ on (TG) and (DTA) analyses constructed and built in our department. The heating rate was of $5 \mathrm{C}^{\circ} \mathrm{min}^{-1}$ and $\alpha-\mathrm{Al}_{2} \mathrm{O}_{3}$ was used as standard reference.

\section{F. Infrared Spectra:}

The absorption spectra of samples under investigation were recorded on FT-IR Tensor-27-Bruker 2004 Spectrophotometer using $\mathrm{KBr}$ pellets and $\mathrm{NaCl}$ cell (William and Fleming, 1981).

\section{G. Application:}

Six chromatographic fractionating columns were prepared which were packed applying both natural and purified silica and their doped samples as adsorbent materials. All samples were of chromatographic grade $(0.212-0.6 \mathrm{~mm})$ and activated to be employed in the processes.

A known weight (2g) of QP was fractionated into four isolated samples according to their adsorption polarities using four eluants of different polarities. IR and NMR will be presented in future article very soon in order to study the chemical nature of the eluted stuff and to evaluate the adsorption activity and selectivity of the investigated samples.

\section{A. Physical and Chemical Characterization:}

\section{RESULTS AND DISCUSSION}

Physical properties (e.g density, porosity, water absorption, pore size and surface area) have been measured following the methods described in the literature (Iler, 1979). Table (1) shows such data related to the six silica samples under investigation .The capillary action was also measured and the rising of water level was observed as monitored with time is taken as the measurement of this action, Figure (1). It is clear that physical properties of these samples show notable differences. It seems that the purified silica sample has low 
density and high porosity and permeability. Meanwhile, the low capillary action of this sample on comparison with natural silica may explain the fact that natural silica samples contain large number of small pores which are well connected by an extremely narrow channels. Moreover, it seems that doping of these samples with chromium complexes affects creating new catalysts with different physical properties. Selenato complexes appeared to be generally the best, regarding adsorption activity (Vartak, 2001) .

$\mathrm{X}$-ray fluorescence and instrumental chemical analysis such as atomic absorption and flame photometry, have been used to study the chemical composition of natural semi-pure Ninivite silica rock, and the data of these analyses are shown in Table (2). On the other hand, it is shown that such sample yield 36.7\% amorphous silica on treating with basic medium (Buker and Taher, 2006). On doping of those samples, the results of analysis reflect the fact that the percentage values of chromium and selenium ions are in the range agrees with the mentioned doping factor molar ratio of 1:8.

\section{B. Structural Studies:}

Since Ninivite silica rocks occurred naturally it is difficult to find a sample containing $100 \%$ silica compounds. Therefore, the natural silica sample indeed bears small quantities of other compounds. Careful X-ray powder diffraction studies reveal the presence of such mixed layer structures and frequently indicate their nature and relative abundance (Buker, 1993).

Accordingly, X-ray powder diffraction for Ninivite silica was carried out. Figure (2) shows the sample pattern which contains reflections typical to quartz in addition to montmonorolonite, illite, alunite and gypsum phases (Cornelis, 1985).

The amorphous silica may also be defined, on the basis of X-ray pattern, as a broad hump between $2 \theta$ (16 and 28) (Brindly and Brown, 1980). However, on doping silica samples with chromium complexes and calcinations to about $700 \mathrm{C}^{\circ}$; in order to obtain good crystalline phases; it seems that the prepared samples were destructed and new phases of chromium and selenium oxides appeared. X-ray diffraction charts of these samples (Buker and Taher, 2006) are modified to the data presented in Tables (3 and 4). This type of presentation clearly indicates the interplanar spacings of the contributing phases present in the above samples. Therefore, all samples under investigation were avoided from heating above $450 \mathrm{C}^{\circ}$ to be active adsorbents whenever they were employed.

The aim of the present study is to prepare a modified silica samples which conation the doped complexes. Such goal to be achieved, differential thermal analysis technique might be employed, followed by thermogravimetric degradation in order to obtain an activated catalyst. Figure (3) shows DTA curve of natural silica sample which contains three endothermic peaks representing the three types of hydration water molecules as reported previously (Buker and AL-Mallah, 2005). Meanwhile, DTA curves of the rest of samples were noted to be similar to the above one except in small variation in the position of the hydration peaks. To interpret such foundation, TG of the investigated samples were performed and Figure (4) represents one of such analyses. It is clear that losses of 14.07,5.18 and 7.4\% from the original weight were observed which correspond to the dehydration phenomena (Stazczuk, 1998).

Finally, it is of interest to study the migration and elimination of the above water molecules from silica samples on increasing the temperature, in addition to the silica 
mineralogy by infrared absorption spectroscopy. Therefore, a range of $400-4000 \mathrm{~cm}^{-1}$ in frequency was applied and the spectra show several absorption bands including those between $\left(1097-1101 \mathrm{~cm}^{-1}\right)$ which may be attributed to the Si-O stretching vibration (Cornelis, 2003). Also, there are absorption bands at $798-802 \mathrm{~cm}^{-1}$ which are related to the Si-O-M groups and those in the range (3625-3742 $\mathrm{cm}^{-1}$ ) which represent the structural $\mathrm{OH}$ groups. Such absorptions show a significant variation in the position and sharpness of the vibrations upon heating the samples in the range of $150-500 \mathrm{C}^{\circ}$. This may be related to the dehydration phenomenon.

\section{Chromatographic Fractionation:}

The above results obtained for the six silica samples in the present research show a significant variation in their chemical compositions, physical properties, and especially in their structural components. It is therefore of interest to get benefit of such findings in evaluating the studied silica samples in order to be applied as good adsorbents in fractionation processes. The silica samples are suitable for the separation of majority of substances or for the separation of complex mixtures into groups of compounds.

Accordingly, six fractionating columns were packed with the chromatographic grade $(0.212-0.6 \mathrm{~mm})$ activated silica samples. They were employed in the fractionation of QP using four eluants increased gradually in their polarities and the results are shown in Table (5). The observed results revealing the percentages of the fractions are, indeed eluted according to their adsorption polarities. In general, it is clear that adsorption and desorption of petrolane materials on silica samples has strongly occurred and as a result separated into four components. However, on referring to the previous studies in this field (Buker and AlMallah, 2005; Buker and Mubarak, 2001), it seems that the best separation and fractionation occurred in case of amorphous silica sample followed by those samples of doped selenato complex of natural silica and amorphous silica, respectively. To prove such proposed result, chemical characteristic nature of the eluted fractions should be studied via IR and NMR techniques and it will be hopefully presented in a future article.

Table 1: Physical Properties of Samples

\begin{tabular}{|c|c|c|c|c|c|c|c|}
\hline Sample & $\begin{array}{c}\text { Density } \\
\mathbf{g} / \mathbf{c m}^{\mathbf{3}}\end{array}$ & Porosity \% & $\begin{array}{c}\text { Por } \\
\text { Size } \\
\mathbf{c m}^{\mathbf{3}} / \mathbf{g}\end{array}$ & $\begin{array}{c}\text { Water } \\
\text { Absorption \% }\end{array}$ & $\begin{array}{c}\text { Surface Water } \\
\text { Absorption \% }\end{array}$ & $\begin{array}{c}\text { Suface } \\
\text { Area } \\
\mathbf{g} / \mathbf{c m}^{2}\end{array}$ & $\mathbf{p H}$ \\
\hline Natural Silica & 0.78 & 98.8 & 1.52 & 76 & 1.08 & 193.5 & 7.89 \\
\hline Selenato doped Silica & 2.18 & 222 & 3.21 & 160 & 16.9 & 65.8 & 7.12 \\
\hline Oxalato doped Silica & 2.22 & 124 & 2.16 & 108 & 25.31 & 189.7 & 8.37 \\
\hline Amorphous Silica & 0.63 & 176 & 3.96 & 198 & 2.11 & 126.5 & 12 \\
\hline $\begin{array}{c}\text { Selenato doped } \\
\text { Amorphous silica }\end{array}$ & 1.8 & 252.7 & 4.3 & 215 & 17.77 & 131.6 & 8.23 \\
\hline $\begin{array}{c}\text { Oxalato doped } \\
\text { Amorphous silica }\end{array}$ & 2.03 & 181.5 & 1.78 & 121 & 34.11 & 63.2 & 8.88 \\
\hline
\end{tabular}


Table 2: Chemical Composition of Natural Silica

\begin{tabular}{|c|c|c|}
\hline Oxides & ICA $^{*}$ Wt.\% & XRF (\%) \\
\hline $\mathrm{SiO}_{2}$ & 90.00 & 86.14 \\
\hline $\mathrm{K}_{2} \mathrm{O}$ & 1.11 & 1.90 \\
\hline $\mathrm{Na}_{2} \mathrm{O}$ & 0.47 & 1.00 \\
\hline $\mathrm{CaO}$ & 3.26 & 3.07 \\
\hline $\mathrm{TiO}_{2}$ & - & 2.74 \\
\hline $\mathrm{Al}_{2} \mathrm{O}_{3}$ & 0.88 & 1.94 \\
\hline $\mathrm{Fe}_{2} \mathrm{O}_{3}$ & 0.48 & 0.94 \\
\hline $\mathrm{MgO}$ & 0.20 & 0.47 \\
\hline $\mathrm{BaO}^{\mathrm{Nb}}$ & - & 0.57 \\
\hline $\mathrm{SO}_{3}$ & - & 1.16 \\
\hline $\mathrm{L}_{5} \mathrm{O} . \mathrm{I}$ & 3.10 & - \\
\hline
\end{tabular}

*Instrumental chemical analysis (atomic absorption and flame photometry ) 
Table 3: Interplanar Spacings of Contributing Phases in Selenato- Doped Silica

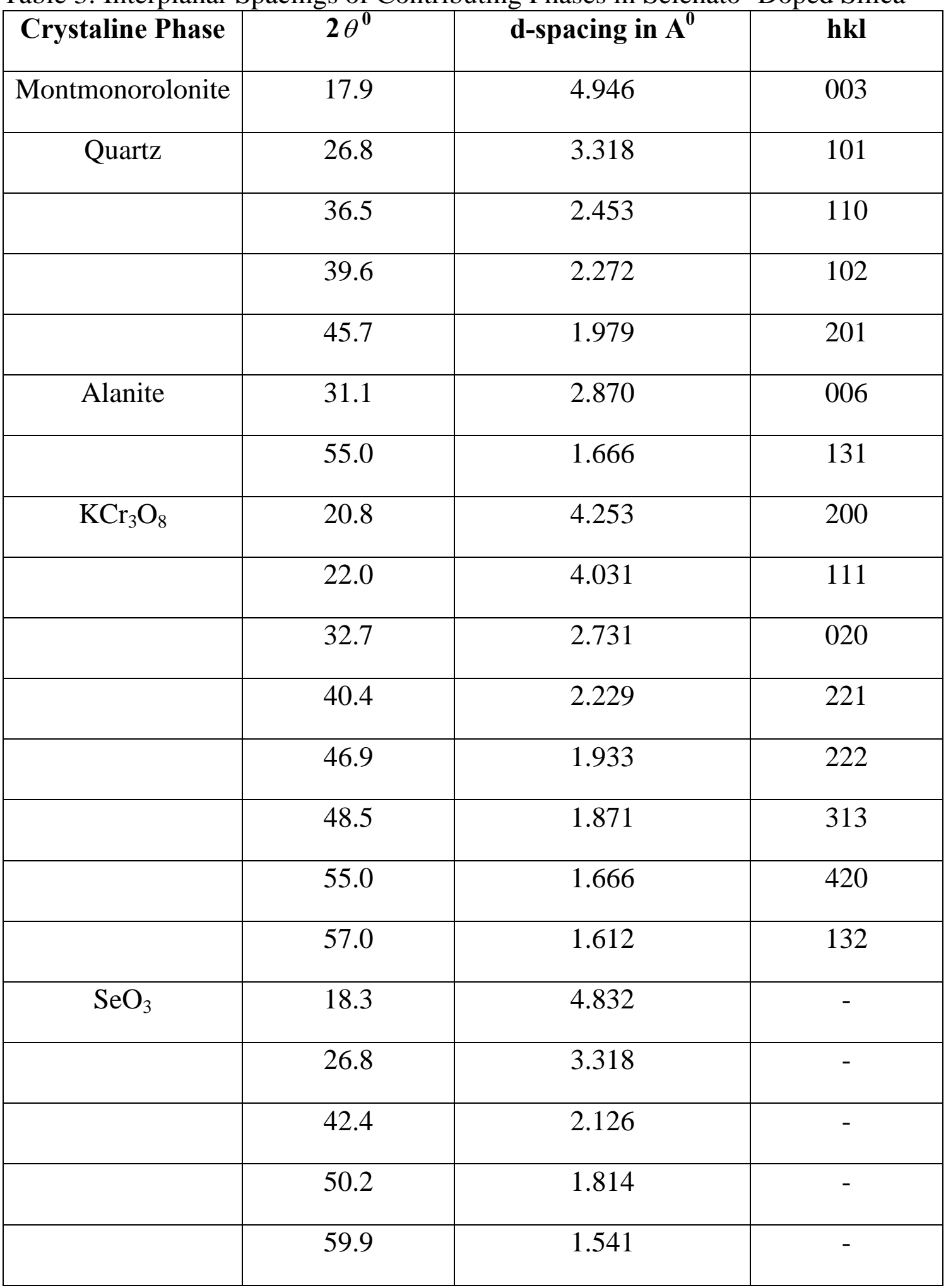


Table 4: Interplanar Spacings of Contributing Phases in Oxalato - Doped Silica

\begin{tabular}{|c|c|c|c|}
\hline Crystaline Phase & $2 \theta^{0}$ & d-spacing in $A^{0}$ & hkl \\
\hline Montmonorolonite & 17.3 & 5.112 & 003 \\
\hline \multirow[t]{9}{*}{ Quartz } & 20.8 & 4.253 & 100 \\
\hline & 26.5 & 3.354 & 101 \\
\hline & 39.3 & 2.287 & 102 \\
\hline & 40.3 & 2.233 & 111 \\
\hline & 45.0 & 2.008 & 200 \\
\hline & 45.7 & 1.979 & 201 \\
\hline & 50.1 & 1.818 & 112 \\
\hline & 54.9 & 1.667 & 103 \\
\hline & 59.9 & 1.541 & 211 \\
\hline \multirow[t]{2}{*}{ Alanite } & 27.8 & 3.204 & 113 \\
\hline & 52.6 & 1.736 & 220 \\
\hline $\mathrm{KCr}_{3} \mathrm{O}_{8}$ & 29.8 & 2.992 & 112 \\
\hline \multirow[t]{8}{*}{$\mathrm{Cr}_{5} \mathrm{O}_{12}$} & 21.9 & 4.048 & 002 \\
\hline & 23.4 & 1.941 & 512 \\
\hline & 28.7 & 3.096 & 221 \\
\hline & 32.3 & 2.767 & 122 \\
\hline & 34.7 & 2.574 & 131 \\
\hline & 38.1 & 2.353 & 322 \\
\hline & 42.2 & 2.134 & 223 \\
\hline & 43.7 & 2.067 & 040 \\
\hline \multirow[t]{4}{*}{$\mathrm{Cr}_{2} \mathrm{O}_{3}$} & 24.3 & 3.654 & 012 \\
\hline & 33.7 & 2.654 & 104 \\
\hline & 36.3 & 2.469 & 110 \\
\hline & 57.3 & 1.604 & 122 \\
\hline
\end{tabular}


Table 5 : Chromatographic Fractions (\%) of 2g QP Using Different Adsorbents

\begin{tabular}{|c|c|c|c|c|c|}
\hline \multirow[b]{2}{*}{ Sample } & \multicolumn{4}{|c|}{ Solvents } & \multirow[b]{2}{*}{ Loss } \\
\hline & $\begin{array}{c}\text { n-hexane } \\
\mathrm{d} \pi^{*}(\mathbf{3 1})\end{array}$ & $\begin{array}{l}\text { Toluene } \\
\qquad \begin{array}{c}\mathrm{d} \pi \\
(33.9)\end{array}\end{array}$ & $\begin{array}{l}\text { Dichloride } \\
\text { Methelen } \\
\mathrm{d} \pi(\mathbf{4 1 . 1})\end{array}$ & $\begin{array}{l}\text { Ethanol } \\
\qquad \begin{array}{c}\mathrm{d} \pi \\
(51.9)\end{array}\end{array}$ & \\
\hline Natural Silica & 1.47 & 0.12 & 0.10 & 0.22 & 0.09 \\
\hline $\begin{array}{c}\text { Selenato - doped } \\
\text { Silica }\end{array}$ & 1.28 & 0.19 & 0.05 & 0.38 & 0.10 \\
\hline $\begin{array}{c}\text { Oxalato - doped } \\
\text { Silica }\end{array}$ & 1.44 & 0.20 & 0.03 & 0.23 & 0.10 \\
\hline $\begin{array}{l}\text { Amorphous } \\
\text { Silica }\end{array}$ & 1.07 & 0.49 & 0.01 & 0.42 & 0.01 \\
\hline $\begin{array}{c}\text { Selenato - doped } \\
\text { Amorphous } \\
\text { silica }\end{array}$ & 1.31 & 0.10 & 0.02 & 0.41 & 0.16 \\
\hline $\begin{array}{c}\text { Oxalato - doped } \\
\text { Amorphous } \\
\text { silica }\end{array}$ & 1.25 & 0.39 & 0.05 & 0.25 & 0.06 \\
\hline
\end{tabular}

*Polarity unit 

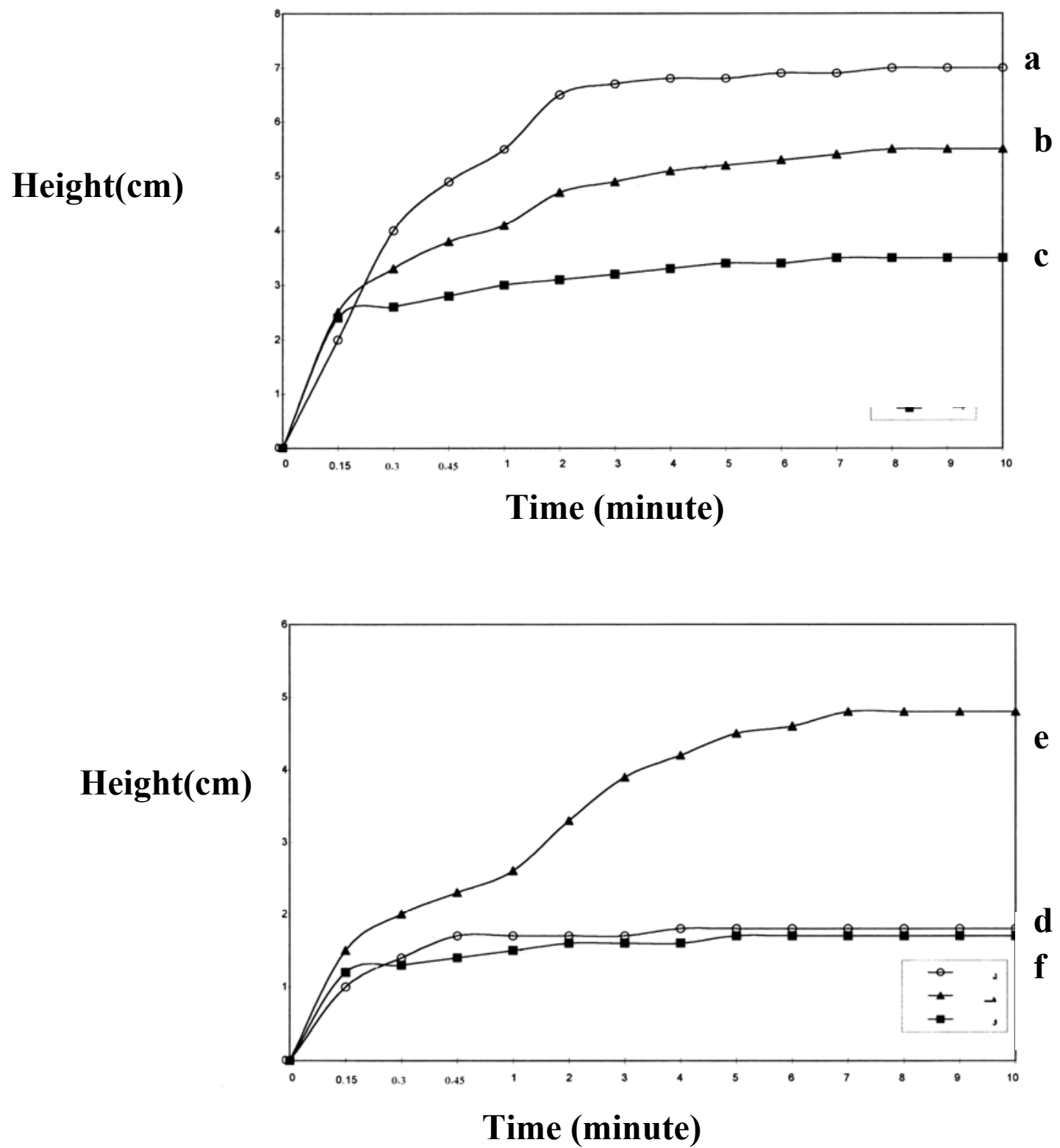

Fig.1 : Capillary Action Curves of :

a-Natural Silica.

b-Selenato - doped Silica.

c-Oxalato - doped Silica.

d-Amorphous Silica.

e-Selenato - doped Amorphous silica.

f-Oxalato - doped Amorphous silica. 
Intensity

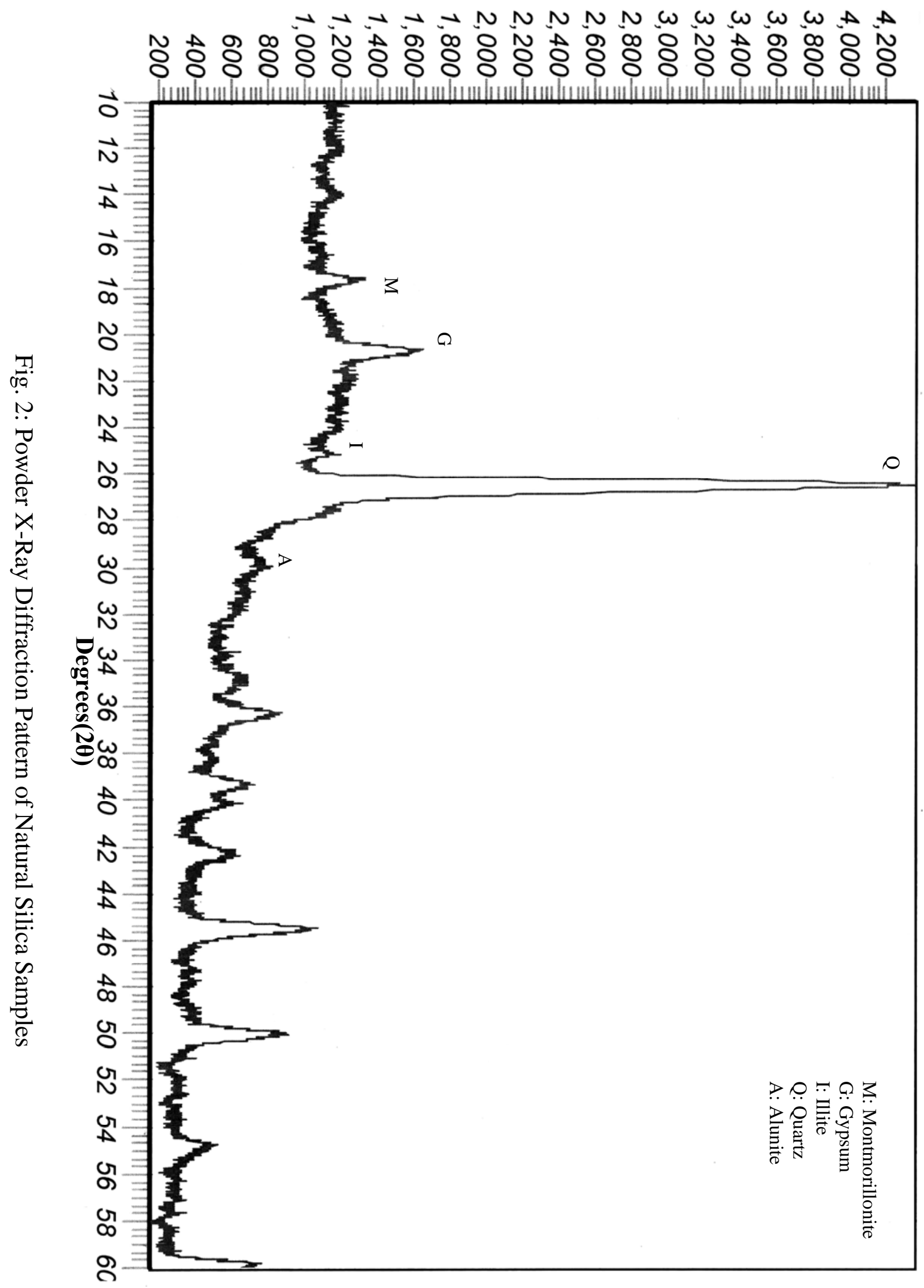




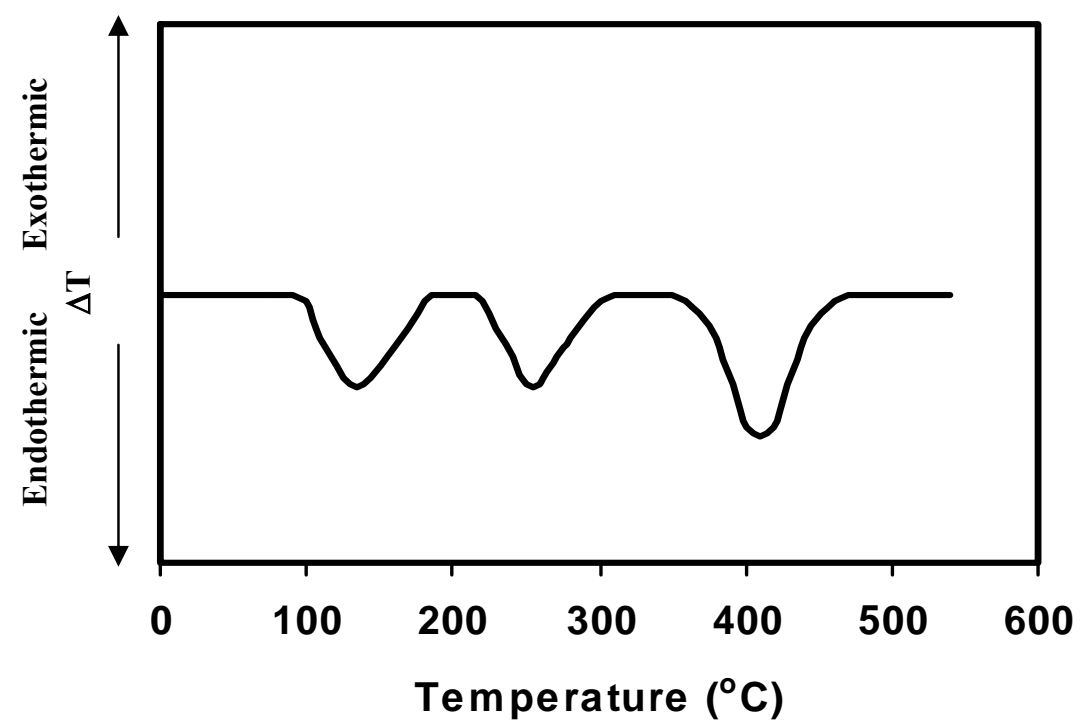

Fig. 3: Differential Thermal Analysis Curve of Natural Silica Sample (Buker and Taher, 2006)

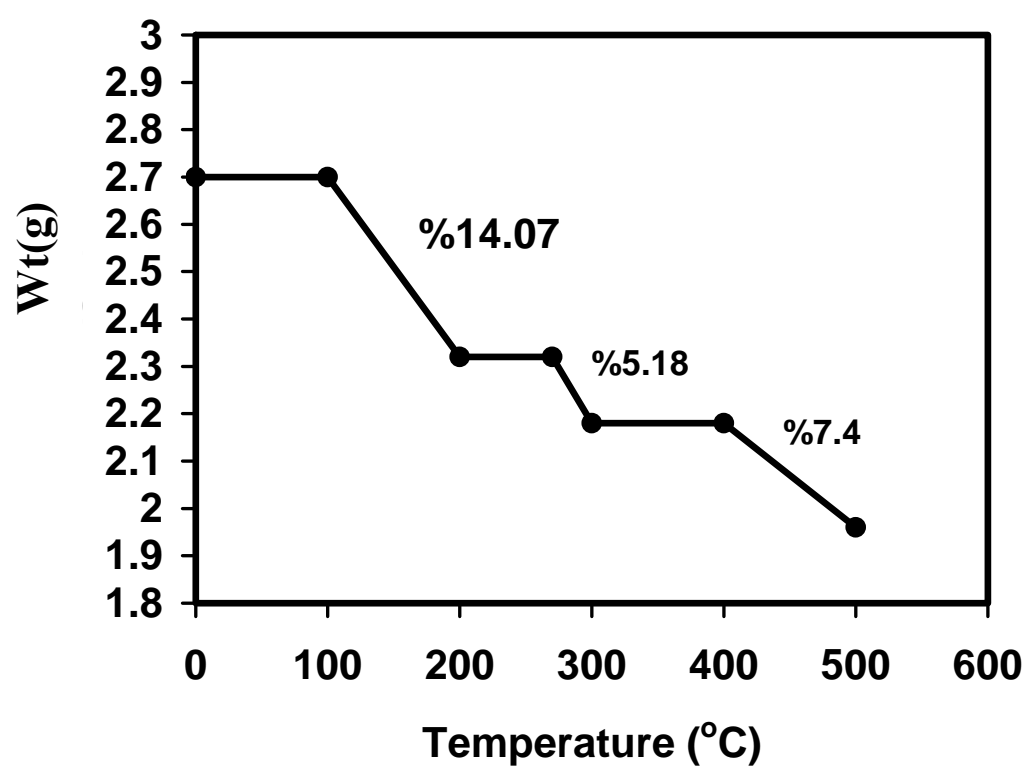

Fig. 4: Thermogravimetric Curve of Natural Silica Sample (Buker and Taher, 2006)

\section{REFERENCES}

Ali, L.H.,Ghanam, K.A.,and AL-Rawi, J.M., 1990. Chemical Structural of Asphaltenes in Heavy Crude Oil , Fuel , 69 , 519p.

Brindly, G.W., and Brown, G., 1980. Crystal Structure of Clay Minerals , Mineralogical Society , London, pp. 15-18,440-444 .

Booth, H.S., 1939. Inorganic synthesis, Vo1. I ,Mc Graw-Hill Book Company ,U.S.A, pp. 37-38. 
Buker, R.A., 1993. Comparison Study of Synthetic and some Natural Iraqi Fullers Earth .J.Chem Soc.Iraq, 18(2), 79 p.

Buker, R.A. and Taher, N.H. , 2000. Ninivite Silica Gel, Characterization and Application in Petroleum Refining. Dirasat , 27,(20),245p.

Buker, R.A. and Mubarak, L.A., 2001. Jarosite Mineral and its Application . Raf. J. Sci.,13,11p.

Buker, R.A. and AL-Mallah, S.A., 2005. Natural Mineral Clays Bearing Feldspar ,Physical and Structural Studies and Application in Petroleum Fractionation. J.Edu.Sci.,17,(4),42p.

Buker, R.A. and Taher, N.H., 2006. Ninivite Silica gel , Doping with Chromium Oxide Gel , Characterization and Application in Solid Phase Extraction. Dirasat, 33,(2),158p.

Cornelis, K. , 1985. Manual of Mineralogy. 12 th Ed., John Wiley, New York, 448 p.

Cornelis, K. , 2003. Mineral Science 2 nd Ed ., John Wiley and Sons , New York, pp. 412479.

Iler, R.K., 1979. The Chemistry of Silica , Solubility and Physical Properties . John Wiley and Sons .U.S.A, pp. 15- 40,49,225.

Jaronies, M., Krut, M. and Zhou, Y., 1997. Nitrogen Adsorption Studes of Coated and Chemically Modified Chromatographic Silica Gels. Langmuir, 13,(3),545p.

Jassim, S.and AL-Naqib, S. , 1989. Ninivite : A New Form of Porcelinite and the Associated Alnnity Jarosite Minerals. J.Geo . Soc . Iraq, 22,(1),112p.

Kang, S. and Choi, S., 2000.Sunitesis of Low Density Silica Gel at Ambient Pressur. J. Mater , Sci , 35 , (19), 4971p.

Kob, N. ,Drago, R. and Yong, V. , 1997. Preparation Characterization and Acidity of a Silica gel Tungeston Oxid Sotid Acid . Inorg. Chem., 36,(22),5127p.

Kozel, J., 1975. Text Book on Density and Porosity of Rocks, Academic Press , New York., U.S.A, pp. 155-170.

Parentis, M. , Bonini, N., and Gonzo, E., 2001. Silica Supported Chromium Catalyst: Reactivity Studies with Alcohol. React .Kinet , Catal Lett., 22(2),303p.

Ramadhan, O.M., 1992. Application of Natural and Synthetic Fullers Earth to the Fractionation of Bitument . FSTI,10,221p.

Ramadhan, O.M. and Ghazal, R. , 2004. Chemical and Physical Studies of Natural Bentonite, Nat. J.Chem , 16,43p.

Salib, K.A.R. and Buker, R.A., 1983. Selenato complexes : Basic Selenite of Transition Metals. Transition Met.Chem.,8,360p.

Skoog, D.A. and West, D.M., 1976. Fundamentals of Analytical Chemistry. Holt Rinehant , Wineston, pp. 576-581.

Stazczuk, P. , 1998. Studies of the Adsorbed Water Layers Solid Surfaces by Means of the Thermal Analysis Special Techniques. Thermo Acta, 308, (1,2),147p.

Vartak, R.R., 2001. Chromatography an Educational Tool, Mumbai , India .

Williams, D. and Fleming, I., 1981. Spectroscopic Methods of Inorganic Chemistry 4th . Ed, Mc Graw -Hill Book Co., Ltd., London, 97 p. 
